Akingbola (2020)

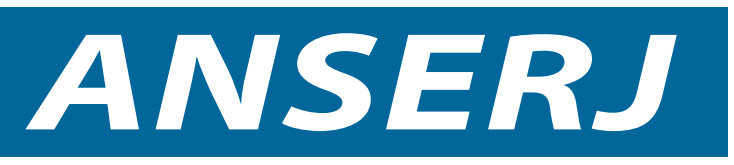

Vol. 11, No. 1

Spring / Printemps 2020

pp. $16-20$

Canadian Journal of Nonprofit and Social Economy Research

Revue canadienne de recherche sur les OBSL et l'économie sociale

\title{
COVID-19: The Prospects for Nonprofit Human Resource Management
}

\author{
Kunle Akingbola \\ Lakehead University
}

\begin{abstract}
This article explores the impacts of COVID-19 on nonprofit employees and human resource management (HRM). The pandemic is wreaking havoc on people's health and well-being and threatening the primary institutions that support the functioning of society. For nonprofits, COVID-19 is a call to action at many levels. As the devasting impacts of the pandemic evolve, nonprofits have continued to provide essential services and help the vulnerable. At the same time, the impacts of COVID-19 portend serious and potentially crippling strains on nonprofits, which are already overstretched. Since the context in which nonprofits operate is critical to their effectiveness and the outcomes of their employment relations, the impacts of COVID-19 could shape nonprofit HRM and employees' ability to assist people.
\end{abstract}

\section{RÉSUMÉ}

Cet article explore les perspectives de COVID-19 pour les employés à but non lucratif et la gestion des ressources humaines. L'ampleur de la pandémie fait des ravages sur la santé et le bien-être des personnes et menace les principales institutions qui soutiennent le fonctionnement de la société. Pour les associations, COVID-19 est un appel à l'action à plusieurs niveaux. Alors que les effets dévastateurs de la pandémie évoluent, les organismes sans but lucratif ont continué de fournir des services essentiels et d'aider les personnes vulnérables de la communauté. Dans le même temps, les impacts de COVID-19 présagent des tensions graves et potentiellement paralysantes sur les organisations à but non lucratif déjà surchargées. Étant donné que l'environnement est essentiel à l'efficacité des organisations à but non lucratif et à leurs relations d'emploi, les impacts de COVID-19 pourraient façonner la GRH à but non lucratif et la capacité d'aider les communautés, les personnes et leur organisation.

Keywords / Mots clés COVID-19; Nonprofit HRM; Nonprofit Employees; Nonprofit Change / COVID-19; GRH à but non lucratif; Employés à but non lucratif; Changement à but non lucratif

\section{INTRODUCTION}

Nonprofits play a critical role in helping the community to mitigate and solve problems at different levels and dimensions (Miller-Stevens, Taylor, \& Morris, 2015; Smith \& Phillips, 2016). Even after the problem-solving process is in full swing, nonprofits are adept at pivoting to help the community adapt to change. The COVID-19 pandemic is without a doubt a 


\section{Akingbola (2020)}

problem of unimaginable scale that requires nonprofits to deploy their core competencies and capabilities to assist the community. The way nonprofits manage their human resources $(\mathrm{HR})$ is critical to achieving this objective.

This article explores the impacts of COVID-19 on nonprofit employees and human resource management (HRM). It links current reports on the pandemic to research in order to address two overarching questions: What are the major impacts of COVID-19 on nonprofit employees? How would the impacts influence the direction of nonprofit human resource management (NHRM)? It is important for nonprofit practitioners and researchers to understand these impacts in order to address emergent and heightened HR challenges affecting the sector.

\section{NONPROFIT EMPLOYEES, HRM, AND COVID-19}

The impacts of COVID-19 on nonprofit employees and HRM straddle individual, team, and organizational levels of analysis; therefore, this discussion is categorized into those same three levels of analysis. It is important to note, however, that the impacts overlap and combine to shape NHRM in the short and long term.

\section{Organizational-level impacts}

Layoffs and human resource pool

COVID-19 has resulted in significant layoffs in nonprofits. According to projections by Imagine Canada (2020), nonprofits could lose more than 117,000 employees and $\$ 9.5$ billion in revenue as a result of the COVID-19-related social distancing and economic downtown. Even worse, the layoff and loss projections could increase to 194,000 employees and $\$ 15.6$ billion over six months. Reports in the US have similarly highlighted layoffs as one of the major impacts of the pandemic (Bell \& Dell, 2020).

The layoffs are a critical drain on the HR pool and will create holes in the human capital of nonprofits. Even if nonprofits do eventually recover the lost employees, the layoffs will have a long-lasting impact on their core competencies (Lee \& Wilkins, 2011). Although many nonprofits are adept at navigating occasional layoffs, due mainly to precarious funding, the scale and speed of the COVID-19-related layoffs will hamper their ability to maintain institutional knowledge and attract and retain employees (Castaneda, Garen \& Thornton, 2008; Selden \& Sowa, 2015). The new competencies that nonprofits are developing from the experience of COVID-19 could be lost due to the layoffs that result from the pandemic.

\section{Remote work}

Telecommuting, including for service delivery, has been one of the most transformational workplace shifts attributed to COVID-19. While an increasing number of nonprofit employees were working remotely prior to COVID-19 (Nonprofit HR, 2016), the pandemic has forced a record increase in remote work. Nonprofits are poised to benefit from offering a flexible work schedule and the opportunity to attract employees who value work-life balance (Christie, 2020). However, nonprofits will need to develop HR practices to address issues related to remote work, such as mental health concerns due to the isolation, the impacts on team dynamics, and the legal considerations related to interactions between clients and employees who work from home.

\section{Health and safety}

The number of COVID-19 cases and deaths in nursing and long-term care homes, many of which are nonprofits, have elevated concerns about employee health and safety in Canada and the US (Honan, Brody, \& Calfas, 2020; Weeks, Mahoney, Stone, \& Ha, 2020). Nonprofit frontline employees have also raised concerns about protective equipment and psychological safety in the workplace. These point to the potential COVID-19 has to place a new focus on health and 


\section{Akingbola (2020)}

safety in nonprofits. Although research has highlighted concerns about nonprofit employee well-being due to employment conditions (Baluch, 2017), there is a lack of emphasis on and gap in the understanding of health and safety in nonprofits. COVID-19 has signified the need to prioritize health and safety, including emotional health, and commit resources to it.

\section{HR scenario planning}

The pandemic has revealed the glaring need for NHRM scenario planning in a crisis. While most nonprofits have experienced limitations with respect to service delivery and program cancellation as well as major fundraising challenges as a result of COVID-19 (Catchafire Team, 2020), the inability to continue social justice-oriented programs has highlighted a missed opportunity to deploy employees during the pandemic. For example, a talent exchange program could help nonprofits to share employees between organizations experiencing increased demand with those experiencing less demand (Christie, 2020). The HR scenario plan could address questions regarding which programs to prioritize, the competencies required to deliver the programs, the required resources, and how to support the employees during a pandemic. The plan could help nonprofits to manage the transition to online service delivery and restart in-person service delivery after the pandemic.

\section{Employee-level impacts}

Each of the impacts of COVID-19 on NHRM at the organizational level directly affects employees. For example, layoffs are occurring at a time when there is an increase in demand for the services of nonprofits. These have implications for workload, precarious work security, and the job satisfaction of employees after the pandemic (Cunningham \& James, 2017; Howe \& McDonald, 2001). In addition to the organizational-level impacts, it is important to highlight two effects of COVID-19 on employees and how they could impact NHRM.

\section{Employee voice}

The need to make urgent decisions in response to COVID-19 means that nonprofit leaders are not seeking inputs and engaging employees, even on decisions that affect them (Levine, 2020). Although research suggests that nonprofit employees are engaged and participate in the decision-making process (Akingbola \& van den Berg, 2017), the pandemic has shown that employees feel disempowered and lack information about issues that impact them. This disengagement means that employees are reluctant to raise issues, even when they have legitimate concerns about the workplace, including safety (Villarreal, 2020). Employee voice is critical not only during COVID-19 but also in the long-term recovery of an organization's community problem-solving role. The lack of employee voice during the pandemic will impact employee relations in nonprofits long after the pandemic.

\section{Hazard pay}

COVID-19 has raised questions about hazards in nonprofit organizations. Although nonprofit employees provide essential services, the pay is low and they are known to have intrinsic motivation (Atkinson \& Lucas, 2013; Borzaga \& Tortia, 2006). Advocacy for hazard pay has resulted in governments and employers in Canada and the US providing it for some nonprofit employees delivering essential services. Thus, the impacts of COVID-19 have drawn attention to potential rationale for hazard pay in nonprofits, such as harassment, violence, and the high level of stress on the job (Baines, 2010). Questions about hazard pay will likely be one of the emergent issues in NHRM after the pandemic.

\section{Team-level impacts}

\section{Collaboration}

COVID-19 has had team-level impacts on nonprofit employees, including their ability to collaborate. Nonprofit employees typically have more opportunities to participate in decision-making through teams and work on committees (Kalleberg, Marden, Reynolds, \& Knoke, 2006). With many employees working remotely due to the lockdown, COVID-19 is redefining 


\section{Akingbola (2020)}

the nature of collaboration among nonprofit employees. For many nonprofits and their employees, this will require new learning in order to optimize the use of technology. The lack of preparation in this regard is a challenge to collaboration among team members. Moreover, due to the interpersonal nature of the services offered by nonprofits and the characteristics of their employees, there are concerns about the impacts of limited collaboration on the emotional health of the team (Cooks, Aisen, Oberman, Levine, \& Katler, 2020). NHRM must therefore pay attention to the challenges of remote work when it comes to team collaboration. This would include equipping employees with the knowledge and skills required to work in an effective team environment that is facilitated by technology.

\section{CONCLUSION}

The discussion of the impacts of COVID-19 on nonprofit employees provides an overview of the ways the pandemic could shape NHRM. While some of the impacts, such as remote work, hazard pay, and health and safety concerns, are new issues facing NHRM in both the short and long term, the layoffs and lack of employee voice will renew focus on the impacts of these implications for nonprofit management and in research. Nonprofit leadership and funders must understand and implement strategies to address these major NHRM issues.

\section{REFERENCES}

Akingbola \& van den Berg. (2017). Antecedents, consequences and the context of employee engagement in nonprofit organizations. Review of Public Personnel Administration, doi: 10.1177/0734371X16684910

Atkinson, C., \& Lucas, R. (2013). Worker responses to HR practice in adult social care in England. Human Resources Management Journal, 23(3), 296-312.

Baines, D. (2010). If we don't get back to where we were before: Working in the restructured non-profit social services. British Journal of Social Work, 40(3), 928-945.

Baluch, A. (2017). Employee perceptions of HRM and well-being in nonprofit organizations: Unpacking the unintended. International Journal of Human Resources Management, 28(14), 1912-1937.

Bell, J., \& Dell, S. (2020). It's different this time: Handling nonprofit staff cuts under COVID-19. Nonprofit Quarterly. URL: https://nonprofitquarterly.org/its-different-this-time-handling-your-nonprofits-staffing-under-covid-19/ [April 15, 2020].

Borzaga, C., \& Tortia, E. (2006). Worker motivation, job satisfaction and loyalty in public and nonprofit social services. Nonprofit and Voluntary Sector Quarterly, 35(2), 225-248.

Castaneda, M., Garen, J., \& Thornton, J. (2008) Competition, contractibility, and the market for donors to nonprofits. Journal of Law, Economics, and Organization, 24(1), 215-246.

Catchafire Team. (2020). We had a shoestring budget in good times: COVID-19's devastating impact on the nonprofit sector. URL: https://catchafireblog.org/we-had-a-shoestring-budget-in-good-times-covid-19-s-devastating-impacton-the-nonprofit-sector-434df2d5f78b [April 15, 2020].

Christie, B. (2020, April 24). Remote work, talent sharing could expand beyond COVID-19. Workspan. URL: https:// www.worldatwork.org/workspan/articles/remote-work-talent-sharing-could-expand-beyond-covid-19 [April 29, 2020].

Cooks, G., Aisen, I., Oberman, A., Levine, A., \& Katler, A. (2020). What we're hearing from the field April 6-24, 2020. eJewish Philanthropy. URL: https://ejewishphilanthropy.com/what-were-hearing-from-the-field-april-6-24-2020 [April 28, 2020].

Cunningham, I., \& James, P. (2017). Analysing public service outsourcing: The value of a regulatory perspective. Environment and Planning C - Government and Policy, 35(6), 958-974.

Honan, K., Brody, L., \& Calfas, J. (2020, May 5). U.S. deaths top 71,000, as impact on nursing homes mounts. WSJ. URL: https://www.wsj.com/articles/coronavirus-latest-news-05-05-2020-11588669450 [May 6, 2020].

Howe, P., \& McDonald, C. (2001). Traumatic stress, turnover and peer support in child welfare. Washington, DC: Child Welfare League of America. 


\section{Akingbola (2020)}

Imagine Canada Press Release. (2020, March 26). COVID-19 threatens to devastate Canada's charities. Imagine Canada. URL: https://www.imaginecanada.ca/en/360/covid-19-threatens-devastate-canadas-charities [April 15, 2020].

Kalleberg, A.L., Marden, P., Reynolds, J., \& Knoke, D. (2006). Beyond profit! Sectoral difference in high-performance work practices. Work and Occupations, 33(3), 271-302.

Lee, Y., \& Wilkins, V.M. (2011). More similarities or more differences? Comparing public and nonprofit managers' job motivations. Public Administration Review, 71(1), 45-56.

Levine, M. (2020, April 27). The best decision ever: One nonprofit's extraordinary COVID-19 choice. Nonprofit Quarterly. URL: https://nonprofitquarterly.org/the-best-decision-ever-one-nonprofits-extraordinary-covid-19-choice [April 15, 2020].

Miller-Stevens, K., Taylor, J.A., \& Morris, J.C. (2015). Are we really on the same page? An empirical examination of value congruence between public sector and nonprofit sector Managers. VOLUNTAS, 26(6), 2424-2446.

Nonprofit HR (2016). Nonprofit employment practices survey. URL: https://www.nonprofithr.com/wp-content/uploads /2016/04/2016NEPSurvey-final.pdf [April 15, 2020].

Selden, S.C., \& J.E. Sowa. (2015). Voluntary turnover in nonprofit human service organizations: The impact of high performance work practices. Human Service Organizations: Management, Leadership \& Governance, 39(3), 182-207.

Smith, S.R. \& Phillips, S.D. (2016). The Changing and Challenging Environment of Nonprofit Human Services: Implications for Governance and Program Implementation. Nonprofit Policy Forum 7(1), 63-76

Villarreal, A. (2020, May 5). Scared and sick amid Covid-19: US nursing home workers afraid to blow the whistle. Guardian. URL: https://www.theguardian.com/world/2020/may/05/us-nursing-homes-coronavirus-outbreak [May 6, 2020]. Weeks, C., Mahoney, J., Stone, L., \& Ha, T. (2020, April 13). Outbreaks at seniors' homes linked to almost half of COVID-19 deaths in Canada, Theresa Tam says. Globe and Mail. URL: https://www.theglobeandmail.com/canada larticle-outbreaks-at-seniors-homes-linked-to-almost-half-of-covid-19-deaths/ [April 15, 2020].

\section{ABOUT THE AUTHOR / L'AUTEUR}

Kunle Akingbola is Associate Professor of Human Resource Management \& Organizational Behaviour at Lakehead University. His research focus is on complex interactions that shape employee behaviour, HRM, and change. Email: kakingbola @lakeheadu.ca . 